\title{
Ecological advantages of toxin production by the dinoflagellate Alexandrium minutum under phosphorus limitation
}

\author{
Cástor Guisande*, Máximo Frangópulos, Isabel Maneiro, Alba Ruth Vergara, \\ Isabel Riveiro
}

Facultad de Ciencias del Mar, Universidad de Vigo, Lagoas-Marcosende, 36200 Vigo, Spain

\begin{abstract}
Unialgal and mixed cultures of the toxic dinoflagellate Alexandrium minutum and the non-toxic dinoflagellate Prorocentrum micans were cultured under phosphate (P) limitation $(<1 \mu \mathrm{M})$, in the presence or absence of the copepod Acartia clausi. The aim was to determine the possible effects of interspecific competition, predation and nutrient limitation on the production of Paralytic Shellfish Poisoning (PSP) toxin by A. minutum. The growth rate of A. minutum was higher in the cultures of $A$. minutum and copepods than in the mixed cultures of A. minutum and P. micans, which indicates that $A$. minutum was more negatively affected by interspecific competition than by predation. Toxin content per cell in A. minutum increased in all cultures, but toxin production rate was higher in cultures with $P$. micans and/or A. clausi. Toxin concentration in A. minutum increased as $\mathrm{PO}_{4}^{3-}$ concentration diminished. In the mixed cultures with copepods, analyses of toxin content in the copepods showed that at cell toxin contents lower than approximately $20 \mathrm{fmol} \mathrm{cell}^{-1}$, mainly cells of A. minutum were ingested by copepods, whereas at higher toxins content per cell, copepods fed mainly on $P$. micans. We conclude that one of the possible advantages of toxin production by $A$. minutum under $\mathrm{P}$ limitation is to enhance interspecific competition, by redirecting grazing pressure to non-toxic phytoplankton species. It would allow a possibly low competitive ability of $A$. minutum to be offset under low nutrient concentrations.
\end{abstract}

KEY WORDS: Dinoflagellates $\cdot$ Phosphorus $\cdot$ Nutrients $\cdot$ Toxins $\cdot$ Copepods $\cdot$ Predation $\cdot$ Interspecific competition

\section{INTRODUCTION}

It is not yet clear why some marine dinoflagellates produce toxins. Although toxins are supposed to act as feeding deterrents, many studies have shown that toxic algae are ingested by grazers (Huntley et al. 1986, Ives 1987, Carlsson et al. 1995, Turriff et al. 1995, Teegarden \& Cembella 1996, Dutz 1998, Maneiro et al. 2000, Frangópulos et al. 2000). Other explanations for toxicity other than grazing deterrence include precursors for subcellular organelles, cell-wall degradation products, nucleic acid synthesis, nitrogen storage, and

*E-mail: castor@uvigo.es inhibition of competing co-occurring phytoplankton species (see Turner \& Tester 1997). One of the most recent explanations is that some toxins may serve as pheromones (Wyatt \& Jenkinson 1997).

Toxin synthesis in marine phytoplankton species is not a constitutive component of algal metabolism, but both toxin content and toxin composition of algae are influenced by environmental growth conditions (Plumley 1997). Cell toxin content of dinoflagellates has been shown to be associated with changes in temperature (Ogata et al. 1987, Anderson et al. 1990), salinity (Parkhill \& Cembella 1999), light (Ogata et al. 1987, Parkhill \& Cembella 1999) and nitrogen (N) and phosphorous (P) availability (Boyer et al. 1987, Anderson et 
al. 1990). Although all these studies have shown that cellular toxicity of dinoflagellates can be enhanced under a wide range of different environmental conditions, as toxin production is closely coupled to growth rate and there is also a linkage between growth rate and the abiotic factors, the direct link between these abiotic factors and toxin production can not be clearly separated from the effect of growth on toxin production (Anderson et al. 1990).

The exception to this linkage between toxin production and cell division is the enhanced toxin production observed in some toxic dinoflagellates under nutrient limitation (Anderson et al. 1990). A connection between nutrient limitation and enhanced cell toxicity has been observed in dinoflagellates that produce Paralytic Shellfish Poisoning (PSP) toxins (Boyer et al. 1987, Anderson et al. 1990, Béchemin et al. 1999, John \& Flynn 2000), Diarrhetic Shellfish Poisoning (DSP) toxins (Johansson et al. 1996), and in other toxic marine phytoplankton species such as haptophytes (Johansson \& Granéli 1999a,b).

As dinoflagellates seem to produce more toxins under nutrient limitation, toxin production could be an adaptation evolved to offset the negative effects of interspecific competition. Therefore, in addition to abiotic factors, cellular toxicity could also be affected by biotic factors. However, the combined effect of nutrient limitation, interspecific competition and predation on dinoflagellate toxin production has not been reported.

The toxic dinoflagellate Alexandrium minutum, the non-toxic dinoflagellate Prorocentrum micans and the copepod Acartia clausi often co-occur in Ría de Vigo, Spain. To test the possible effects of interspecific competition, predation and nutrient limitation on toxin production of A. minutum several experiments were carried out with unialgal and mixed cultures of the toxic and non-toxic dinoflagellates cultured under nutrient limiting conditions, in the presence or absence of the copepod A. clausi.

\section{MATERIALS AND METHODS}

Zooplankton collection. Zooplankton were collected by vertically integrated tows from a depth of $20 \mathrm{~m}$ to the surface, at a field station $39 \mathrm{~m}$ deep located in Ría de Vigo, Spain $\left(42^{\circ} 13.3^{\prime} \mathrm{N}, 8^{\circ} 47.7^{\prime} \mathrm{W}\right)$. Samples were transported within $2 \mathrm{~h}$ of collection to the laboratory, and adults females of Acartia clausi were sorted out for the experiments.

Experimental design. The non-axenic strain of Alexandrium minutum (AL 1V) and the strain of Prorocentrum micans used in this study were isolated from the Galician rias and came from long-established populations cultured in the Instituto Español de Oceanografía,
Vigo, Spain. This toxic strain of $A$. minutum only contains gonyautoxins 1, 2, 3 and 4 (GTX1-4) (Franco et al. 1994). Filtering efficiency is a function of the diameter of the algal species; for Acartia clausi feeding on A. minutum and P. micans it is $100 \%$ (Donaghay \& Small 1979).

Cultures of $75 \mathrm{ml}$ of diluted $\mathrm{K}$ medium in $100 \mathrm{ml}$ beakers with Alexandrium minutum (ALEX, 12 replicates), A. minutum and 1 copepod (ALEX-1C, 20 replicates), A. minutum and Prorocentrum micans (ALEXPRO, 12 replicates), A. minutum, P. micans and 1 copepod (ALEX-PRO-1C, 100 replicates), and A. minutum, P. micans and 3 copepods (ALEX-PRO-3C, 20 replicates) were grown at $15^{\circ} \mathrm{C}$ on a $12: 12 \mathrm{~h}$ light:dark cycle and with an illumination of $50 \mu \mathrm{mol}$ photon $\mathrm{m}^{-2} \mathrm{~s}^{-1}$ provided by 4 cool-white fluorescent tubes. Replicates $(n=80)$ of the ALEX-PRO-1C experimental culture were used to for the estimation of toxin content in the copepods. The culture medium was prepared with aged natural sea water (salinity of $33.1 \%$ ) filtered through GF/F Whatman filters and autoclaved. As PSP toxins are nitrogenous compounds (approx. 33\% of PSP toxin weight is $\mathrm{NH}_{4}{ }^{+}$) and, hence, $\mathrm{N}$ is necessary for toxin biosynthesis (Flynn et al. 1994), the initial concentrations of $\mathrm{NH}_{4}^{+}$ and $\mathrm{NO}_{3}^{-}$were high enough to avoid $\mathrm{N}$ limitation during the experiment. Mean $\pm \mathrm{SE}$ of the initial nutrient concentrations (in $\mu \mathrm{M}$ ) were $1.19 \pm 0.02$ for $\mathrm{PO}_{4}{ }^{3-}$, $198.71 \pm 0.15$ for $\mathrm{NO}_{3}{ }^{-}$and $5.53 \pm 0.11$ for $\mathrm{NH}_{4}{ }^{+}$.

Every $3 \mathrm{~d}$ cell abundance, toxins content per cell and the concentration of $\mathrm{NH}_{4}{ }^{+}, \mathrm{NO}_{3}{ }^{-}$and $\mathrm{PO}_{4}{ }^{3-}$ were analyzed for each replicate. Copepod toxin content was also analyzed every $3 \mathrm{~d}$ but the first value was analyzed on the sixth day of the experiment to allow copepods to acclimate. Samples of 5 and $2 \mathrm{ml}$ of each experimental replicate were removed for toxin analyses and cell abundance estimation, respectively. Cell densities were determined by counting cell number present in $1 \mathrm{ml}$ in a Sedgewick-Rafter chamber. Algal cells removed from 3 replicates of each experimental culture were pooled and filtered on pre-combusted $13 \mathrm{~mm}$ GF/C Whatman filters for toxin analyses. Therefore, the volume filtered on each filter for toxin analyses was $15 \mathrm{ml}$. The filtered water was used to estimate nutrient concentrations. The concentrations of $\mathrm{NH}_{4}{ }^{+}, \mathrm{NO}_{3}{ }^{-}$and $\mathrm{PO}_{4}{ }^{3-}$ in the media were analyzed with a Technicon AAII auto-analyzer. The filters with the material for toxin analyses were stored at $-80^{\circ} \mathrm{C}$ in ultracentrifuge plastic tubes and lyophilized.

Toxin analyses. To estimate cell toxin content of Alexandrium minutum, $400 \mu \mathrm{l}$ of $0.05 \mathrm{M}$ acetic acid was added to the lyophilized material and the sample was homogenized using a pipette tip adapted to fit the shape of the vial. The sample was shaken followed by freezing twice. Finally, the extract was centrifuged twice at $400 \times g$ for $10 \mathrm{~min}$, after which $200 \mu \mathrm{l}$ of the supernatant was carefully collected with a Hamilton syringe, and stored at $-20^{\circ} \mathrm{C}$. 
From the replicates of the ALEX-PRO-1C experimental culture, between 15 and 17 copepods were transferred to distilled water and without delay, all the copepods were collected with a known volume of distilled water (no higher than $40 \mu \mathrm{l}$ ). Copepods were stored at $-80^{\circ} \mathrm{C}$ in ultracentrifuge plastic tubes and lyophilized. Acetic acid (125 $\mu \mathrm{l}, 0.05 \mathrm{M})$ was added to the lyophilized material followed by the same steps described above.

Analysis of the gonyautoxins by high-performance liquid chromatography with fluorescence detection (HPLC-FD) was performed following a modification of the method of Oshima et al. (1989) described by Franco \& Fernández (1993). Chromatographic profiles of Alexandrium minutum cells were determined by duplicate injections of $90 \mu \mathrm{l}$ of extract (diluted with $0.05 \mathrm{M}$ acetic acid, as necessary). Chromatographic profiles of copepods were determined by a single injection of $90 \mu \mathrm{l}$ of the extracts. Toxins from the Certified Reference Material Program of the National Research Council of Canada (Halifax) were used as standards.

Toxicity of Alexandrium minutum, in saxitoxin equivalents (STXeq), was calculated from the HPLC chromatograms. The toxin concentrations were multiplied by a toxin-specific conversion factor to yield toxicity. The specific toxicity conversion factors of the individual toxins were adopted from Oshima (1995) based upon empirical mouse bioassay data determined using purified standards, and assuming the conversion factor of 1 mouse unit $(\mathrm{MU})=0.23 \mu \mathrm{g}$ STXeq for the ddy mouse strain: 567.6 (GTX1), 205.2 (GTX2), 364.3 (GTX3) and 414.7 (GTX4).

Calculation of specific growth rate and net toxin production rate. A specific growth rate $\mu\left(\mathrm{d}^{-1}\right)$ between successive sampling days for each kind of experimental culture was calculated using the equation:

$$
\mu=\frac{\ln \left(N_{1} / N_{0}\right)}{t_{1}-t_{0}}
$$

where $N_{1}$ and $N_{0}$ are cell concentrations at time $t_{1}$ and $t_{0}$, respectively. In those experimental concentrations with copepods no correction has been made of losses of cells due to predation. The difference between the specific growth rate in ALEX-PRO and ALEX-PRO-1C for both Alexandrium minutum and Prorocentrum micans were used an indicator of grazing pressure on both algal species.

Toxin content (fmol cell ${ }^{-1}$ ) was multiplied by $N_{t}$ to yield $T_{t}$, the total toxin concentration (fmol toxin $\mathrm{ml}^{-1}$ culture) at time $t$. Net toxin production rate $R_{\text {tox }}$ (fmol toxin cell ${ }^{-1} \mathrm{~d}^{-1}$ ) was calculated as mentioned by Anderson et al. (1990) using the following equation:

$$
R_{\mathrm{tox}}=\mu \frac{\left(T_{1}-T_{0}\right)}{\left(N_{1}-N_{0}\right)}
$$

\section{RESULTS}

Table 1 shows final concentrations of $\mathrm{NH}_{4}^{+}, \mathrm{NO}_{3}^{-}$and $\mathrm{PO}_{4}^{3-}$ in each kind of experimental culture. The cultures were not $\mathrm{N}$ limited during the experiment, whereas P limitation occured. To compare these nutrient concentrations with those usually found in the field in this region, data from weekly samples collected from Ría de Vigo in 1997 at station $42^{\circ} 14.6^{\prime} \mathrm{N}$, $8^{\circ} 48.5^{\prime} \mathrm{W}$, using a hose divided from 0 to $5 \mathrm{~m}, 5$ to $10 \mathrm{~m}$ and 10 to $15 \mathrm{~m}$ depth, are shown (Centro de Control do Medio Mariño, Xunta de Galicia). The annual mean \pm $\mathrm{SD}$ and range of the nutrient concentrations $(\mu \mathrm{M})$ were $0.91 \pm 0.59$ from 0.01 to $2.99(\mathrm{n}=156)$ for $\mathrm{NH}_{4}^{+}, 4.01 \pm$ 4.19 from 0.01 to $14.1(\mathrm{n}=159)$ for $\mathrm{NO}_{3}^{-}$, and $0.37 \pm 0.19$ from 0.04 to $0.79(\mathrm{n}=157)$ for $\mathrm{PO}_{4}^{3-}$.

Fig. 1 shows cell density of Alexandrium minutum and Prorocentrum micans in the experimental cultures. Daily copepod mortality was approximately $3 \%$. Each replicate was not taken into account if any of the copepods died, and for this reason on Day 12 of the experiment there were no replicates left from culture ALEX-PRO-3C. The highest cell abundance of A. minutum was obtained in culture ALEX, whereas the low-
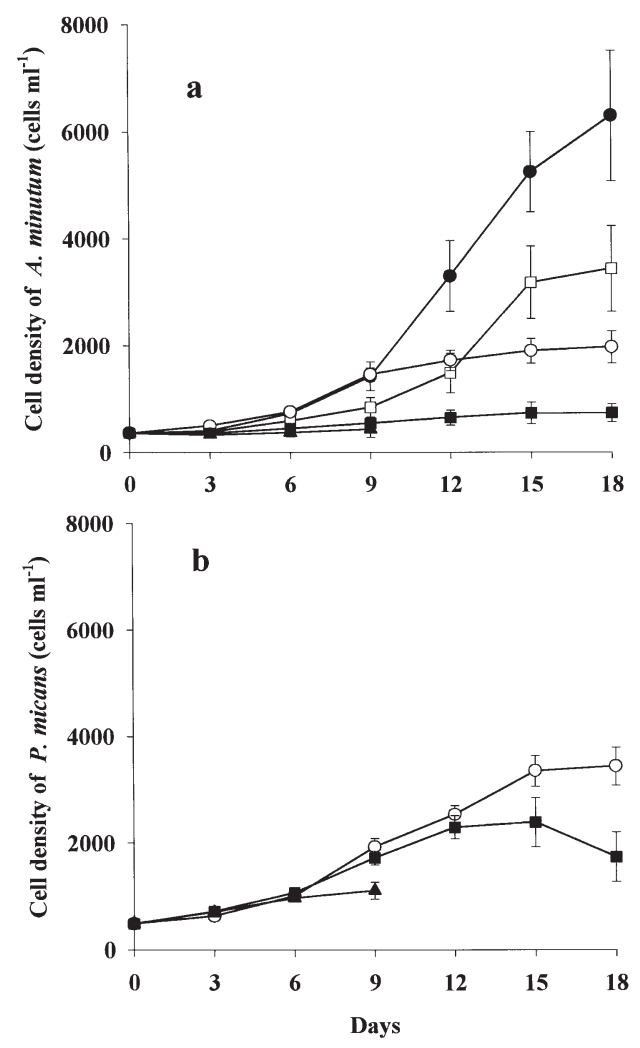

Fig. 1. Cell density (mean $\pm \mathrm{SE}$, cells $\mathrm{ml}^{-1}$ ) of (a) Alexandrium minutum and (b) Prorocentrum micans in the experimental

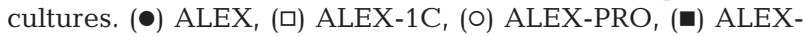
PRO-1C and (ム) ALEX-PRO-3C 
Table 1. Inorganic nutrient concentrations $(\mu \mathrm{M}$, mean $\pm \mathrm{SE})$ at the end of the experiment (Day 18) for each kind of experimental culture

\begin{tabular}{|c|c|c|c|c|}
\hline & ALEX & ALEX-1C & ALEX-PRO & ALEX-PRO-1C \\
\hline $\mathrm{NH}_{4}^{+}$ & $2.97 \pm 0.06$ & $2.88 \pm 0.18$ & $2.83 \pm 0.10$ & $2.77 \pm 0.11$ \\
\hline $\mathrm{NO}_{3}^{-}$ & $88.05 \pm 3.45$ & $112.86 \pm 10.81$ & $83.03 \pm 5.40$ & $103.60 \pm 1.00$ \\
\hline $\mathrm{PO}_{4}{ }^{3-}$ & $0.19 \pm 0.02$ & $0.15 \pm 0.02$ & $0.13 \pm 0.01$ & $0.10 \pm 0.01$ \\
\hline
\end{tabular}

est values were observed in culture ALEX-PRO-1C. This suggests that $A$. minutum was negatively affected by both interspecific competition and predation. In the mixed culture ALEX-PRO the growth of $P$. micans was higher than A. minutum. The growth of $A$. minutum was higher in ALEX-1C than in ALEX-PRO, which indicates that $A$. minutum was more negatively affected by interspecific competition than by predation. Finally, the abundances of $P$. micans in ALEX$\mathrm{PRO}$ and in ALEX-PRO-1C were similar until Day 12 of

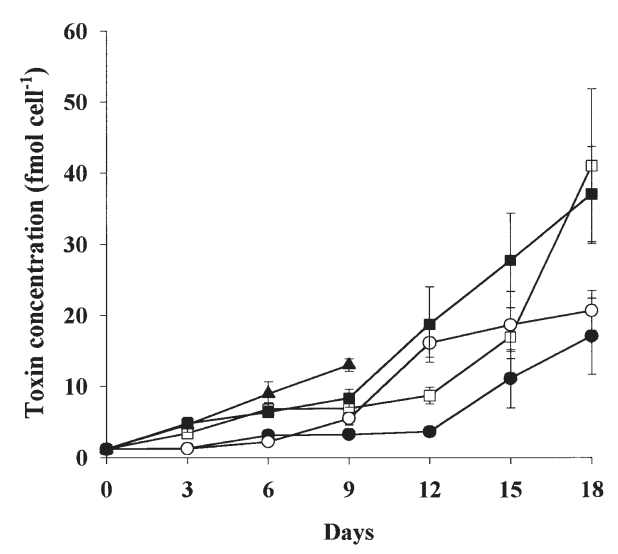

Fig. 2. Alexandrium minutum. Toxin concentration per cell (mean $\pm \mathrm{SE}$, fmol cell ${ }^{-1}$ ) in the experimental cultures. Symbols as in Fig. 1

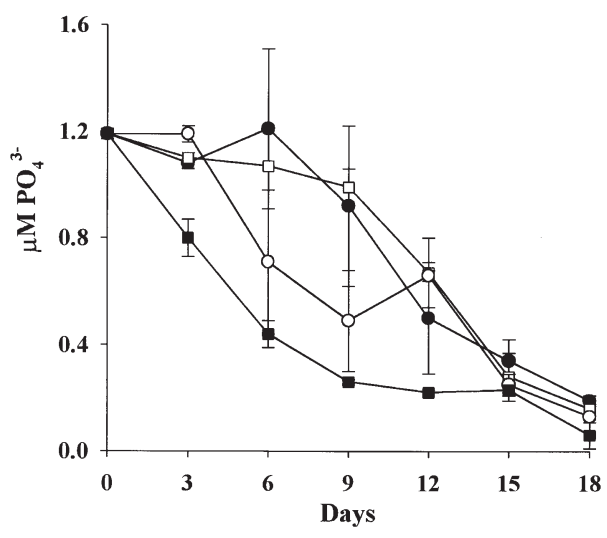

Fig. 3. Phosphate concentration (mean $\pm \mathrm{SE}, \mu \mathrm{M}$ ) in the experimental cultures. Symbols as in Fig. 1 the experiment, when the abundance of $P$. micans was lower in culture ALEX-PRO-1C. Therefore, at the beginning of the experiment copepods fed mainly on A. minutum, whereas at the end of the experiment cells of $P$. micans were also ingested by copepods.

Fig. 2 shows toxic concentration per cell of Alexandrium minutum in the experimental cultures. An analysis of covariance (ANCOVA) taking time into account as covariable, showed that toxic content per cell was lower in ALEX than in ALEX-PRO $\left(F_{1,52}=6.8, \mathrm{p}=0.012\right)$. This suggests that toxin production in $A$. minutum was affected by interspecific competition. Fig. 3 shows $\mathrm{PO}_{4}^{3-}$ decrease in all experimental cultures. Although there were no significant differences between ALEX and ALEX-PRO $\left(F_{1,36}=41.1, \mathrm{p}=0.16\right), \mathrm{PO}_{4}^{3-}$ decreased earlier in ALEX$\mathrm{PRO}$. Moreover, $\mathrm{PO}_{4}^{3-}$ decrease in ALEX-PRO-1C was significantly higher than in ALEX-1C $\left(F_{1,38}=41.1, \mathrm{p}<\right.$ $0.001)$. Therefore, it seems that in those mixed cultures with both dinoflagellate species, A. minutum became P-stressed earlier than Prorocentrum micans.

Toxin production was also affected by predation because toxic content per cell was significantly higher in those experimental cultures with copepods than without copepods: ALEX and ALEX-1C $\left(F_{1,52}=6.0, \mathrm{p}=\right.$ $0.018)$, ALEX-PRO and ALEX-PRO-1C $\left(F_{1,52}=7.5, \mathrm{p}=\right.$ $0.008)$. There were no significance differences in the concentration of $\mathrm{NH}_{4}^{+}$, time taken as the covariable, between ALEX and ALEX-1C (ANCOVA, $F_{1,24}=0.07$,
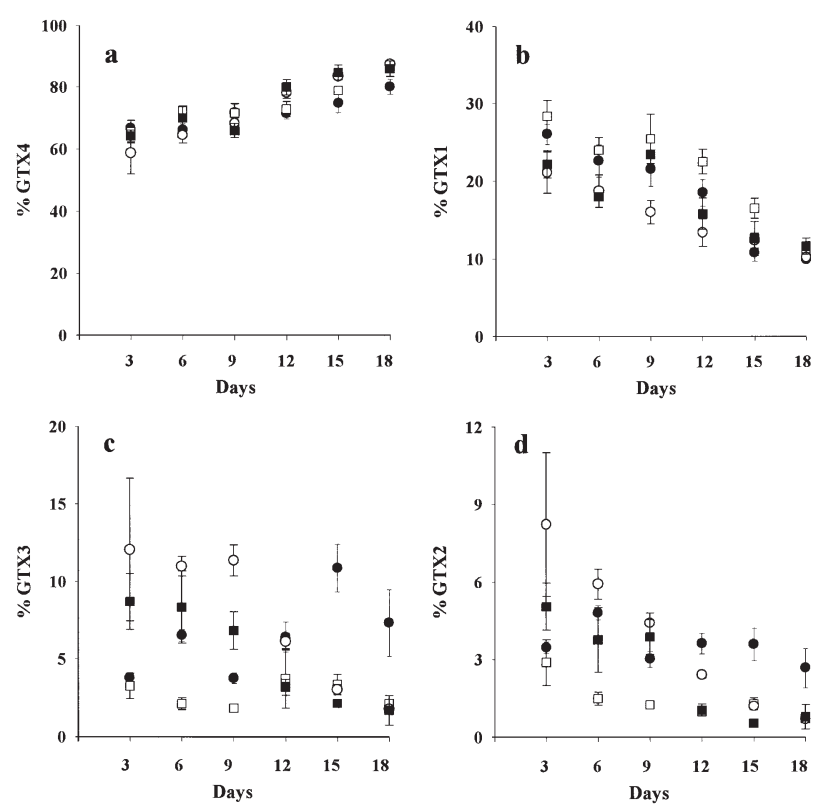

Fig. 4. Alexandrium minutum. Specific toxic composition as percentage of gonyautoxins (GTX1-4) in the experimental cultures. Symbols as in Fig. 1 


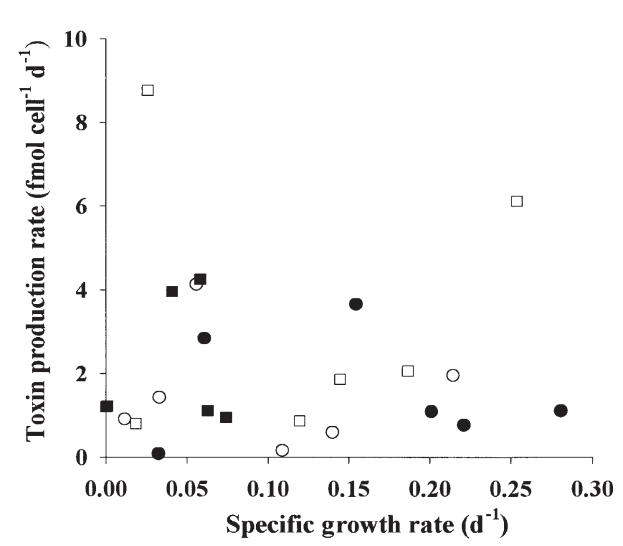

Fig. 5. Alexandrium minutum. Relationship between toxin production rate (fmol cell-1 $\left.\mathrm{d}^{-1}\right)$ and specific growth rate $\left(\mathrm{d}^{-1}\right)$ in the experimental cultures. All SEs were $<0.45$ for toxin production rate and $<0.3$ for specific growth rate. Symbols as in Fig. 1

$\mathrm{p}=0.789)$ and between ALEX-PRO and ALEX-PRO$1 \mathrm{C}\left(F_{1,24}=0.06, \mathrm{p}=0.81\right)$. Therefore, the increase of toxin content per cell in those experimental cultures with copepods was not due to the ammonia excreted by the copepods.

Fig. 4 shows that specific toxic composition of Alexandrium minutum varied over the type of experiment but the change was similar in all experimental cultures. The percentage of GTX4 increased whereas the percentages of GTX1, GTX2 and GTX3 diminished. However, the combined contribution of the isomers GTX1-GTX4 ( 97\%) and GTX2-GTX3 ( 3\%) remains relatively constant over time in all the experimental concentrations.

Fig. 5 shows that the enhanced toxin production observed in all cultures was not associated with growth of Alexandrium minutum (slope different from zero, $F_{1,22}=0.005, p=0.945$ ). Toxin concentration in $A$. minutum was significantly related to $\mathrm{PO}_{4}^{3-}$ concentration. There were significant relationships between $\mathrm{PO}_{4}^{3-}$ concentration $(\mathrm{P})$ and both toxin content per cell (T) $\left(\ln \mathrm{T}=1.232-1.062 \ln \mathrm{P}, \mathrm{r}^{2}=0.68, F_{1,22}=48.2, \mathrm{p}<\right.$
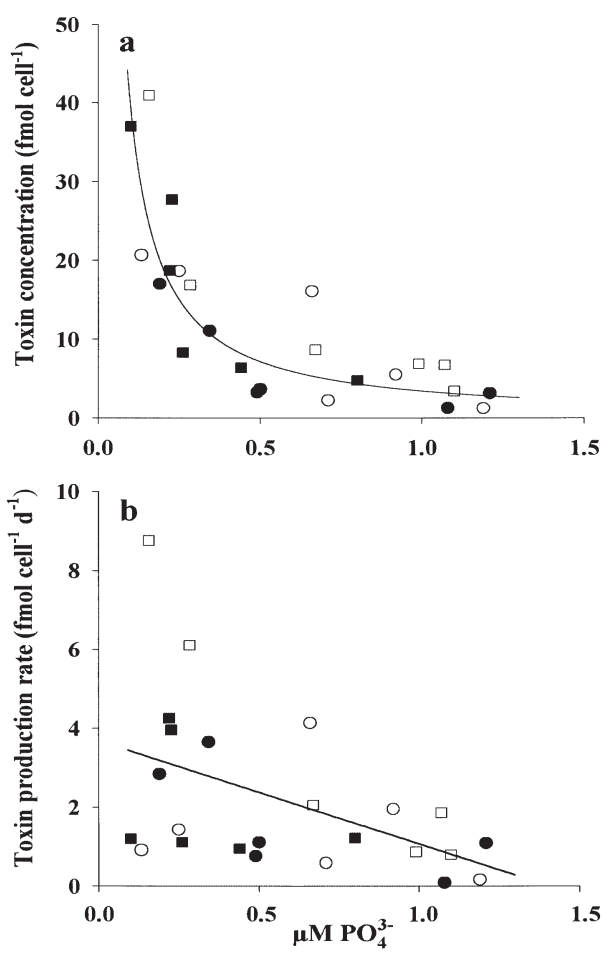

Fig. 6. Alexandrium minutum. Relationships between (a) mean toxin content per cell (fmol cell ${ }^{-1}$ ) and (b) toxin production rate (fmol cell ${ }^{-1} \mathrm{~d}^{-1}$ ) with mean $\mathrm{PO}_{4}{ }^{3-}$ concentration $(\mu \mathrm{M})$. All SEs for toxin content per cell were $<10.9$ and $<0.08$ for $\mathrm{PO}_{4}{ }^{3-}$ concentration. Symbols as in Fig. 1

0.001, Fig. 6a) and $R_{\text {tox }}\left(R_{\text {tox }}=3.689-2.625 \mathrm{P}^{2} \mathrm{r}^{2}=0.23\right.$, $F_{1,22}=6.5, p=0.018$, Fig. 6b).

Copepod toxic content shown in Table 2 confirms that copepods fed on Alexandrium minutum. However, ingestion of $A$. minutum cells decreased as toxin content per cell increased. According to cell toxin content of A. minutum and toxins found in copepods, cells of A. minutum ingested by copepods diminished after Day 9, coinciding with a significant increase in toxin content per cell in A. minutum (Fig. 2). Fig. 7 shows the difference between the specific growth rate in ALEXPRO and ALEX-PRO-1C for both A. minutum and Pro-

Table 2. Specific toxin composition for gonyautoxins (GTX1-4), total toxin per copepod (as the combined GTX1, GTX2, GTX3 and GTX4) and total toxicity potency of Acartia clausi on different experiment days. The equivalent of Alexandrium minutum cells according to cell toxic content at that time and total toxin per copepod is also shown. On Day 18 of the experiment there were not enough copepods for toxin analysis

\begin{tabular}{|c|c|c|c|c|c|c|c|}
\hline Day & GTX4 & $\begin{array}{l}\text { GTX1 } \\
\text { (pmol cop }\end{array}$ & $\begin{array}{r}\text { GTX3 } \\
\left.\operatorname{sepod}^{-1}\right)\end{array}$ & GTX2 & $\begin{array}{l}\text { Total toxin per copepod } \\
\quad\left(\text { pmol copepod }^{-1}\right)\end{array}$ & $\begin{array}{l}\text { Toxicity per copepod } \\
\text { (pg STXeq copepod }^{-1} \text { ) }\end{array}$ & $\begin{array}{l}\text { Equivalent in cells } \\
\text { of } A \text {. minutum }\end{array}$ \\
\hline 6 & 1003.9 & 585.1 & 23.1 & 28.1 & 1640.2 & 0.76 & 257 \\
\hline 9 & 2264.1 & 1080.8 & 42.4 & 75.7 & 3463.1 & 1.58 & 416 \\
\hline 12 & 665.2 & 314.7 & 12.2 & 12.8 & 1005.0 & 0.46 & 54 \\
\hline 15 & 1105.9 & 529.5 & 18.8 & 30.9 & 1685.2 & 0.77 & 61 \\
\hline
\end{tabular}




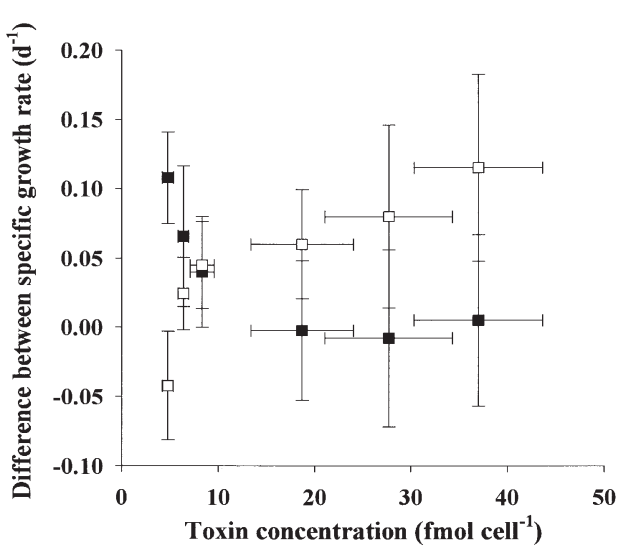

Fig. 7. Relationships between the difference of the specific growth rates of (-) Alexandrium minutum and () Prorocentrum micans in ALEX-PRO and ALEX-PRO-1C $\left(\mathrm{d}^{-1}\right.$, mean $\pm \mathrm{SE}$ ) and toxin concentration of Alexandrium minutum $\left(\mathrm{fmol} \mathrm{cell}{ }^{-1}\right.$, mean $\left.\pm \mathrm{SE}\right)$

rocentrum micans. The specific growth rate in ALEXPRO is higher than in ALEX-PRO-1C for each dinoflagellate species if ingested by the copepods. Therefore, grazing pressure of Acartia clausi on P. micans increased $\left(F_{5,54}=4.3, \mathrm{p}=0.002\right)$ whereas on $A$. minutum de-creased $\left(F_{5,64}=5.02, \mathrm{p}<0.001\right)$ as cellular toxicity of $A$. minutum increased.

\section{DISCUSSION}

The results of this study suggest that one of the possible ecological advantages of Alexandrium minutum is producing toxins to increase grazing pressure on alternative non-toxic competitors under phosphorus limitation. Under $\mathrm{N}$ or P limitation, some toxic dinoflagellates are probably outcompeted. To increase toxin production would provide the dinoflagellates with an opportunity to compete with otherwise superior algal species under the prevailing nutrient limiting conditions. This possible strategy of producing toxins as a mechanism to enhance interspecific competition under nutrient limitation implies two premises: (1) grazers must be capable of discriminating against toxic cells; (2) toxic dinoflagellates may be poor competitors in low nutrient concentrations, which would justify the necessity to have an alternative adaptation to offset the ecological disadvantages of low competitive ability in low nutrient concentrations.

The success of the toxin production strategy of dinoflagellates under nutrient limiting conditions should depend on the presence of grazers and on the capacity of grazers to recognize and to reject toxic cells. It has been shown that copepods can discriminate against toxic dinoflagellates, either by trial and error consump- tion of harmful phytoplankton, allowing copepods to learn which species should be avoided (Uye \& Takamatsu 1990), or by behavioral rejection prior to ingestion (Teegarden 1999). Shaw et al. (1997) showed that PSP toxins and okadaic acid acted as feeding deterrents for the copepod Tigriopus californicus. Our results support the hypothesis that dinoflagellate toxins can act as feeding deterrents, because as cellular toxicity of Alexandrium minutum increased, Acartia clausi ingested a lower amount of cells of A. minutum, but increased grazing pressure on Prorocentrum micans. The differences in cell toxin content between cultures with and without copepods, could simply be due to copepods feeding selectively on cells of A. minutum with a lower toxicity. However, it is necessary to point out that many studies have shown that grazers ingest toxic algae (see Turner et al. 1998). It could be due to low cellular toxicity and/or the incapacity of grazers to detect toxins. As suggested by Teegarden (1999), the presence of toxins could confer the definite advantage of reducing that dinoflagellate's palatability or desirability compared to a non-toxic phytoplankton species, but this does not cause them to avoid or to be selected against by all grazer species. In cases where toxic dinoflagellates are ingested by grazers, this negative effect can be compensated for by reduced reproductive success of grazers due to ingested toxins (Frangópulos et al. 2000).

As mentioned, the second premise is that dinoflagellates should be poor competitors under nutrient limitation. Nutrient uptake affinity $\left(K_{\mathrm{s}}\right)$ is considered an index of species competitive ability at low nutrient concentrations. Smayda (1997) showed that $K_{\mathrm{s}}$ values for $\mathrm{NH}_{4}^{+}, \mathrm{NO}_{3}^{-}$and $\mathrm{PO}_{4}^{3-}$ uptake by dinoflagellates were substantially higher than diatom coefficients. As species with low $K_{\mathrm{s}}$ constants are supposed to be favored under low nutrient conditions, diatoms should be expected to outcompete dinoflagellates under low nutrient supply rates. Yamamoto \& Tarutani (1996) carried out a study with 2 potential competitors that often co-occur in Mikawa Bay (Japan), the toxic dinoflagellate Alexandrium tamarense and the non-toxic diatom Skeletonema costatum. They showed that the specific phosphate uptake rate (uptake rate divided by cellular phosphorous content) was much lower in A. tamarense than in $S$. costatum and furthermore, specific growth rate of $S$. costatum was higher than of $A$. tamarense over a range of $\mathrm{PO}_{4}^{3-}$ between 1 and $12 \mu \mathrm{M}$. It indicated that $A$. tamarense was clearly in a more disadvantaged position to proliferate than $S$. costatum in an environment of any phosphate concentration. Other studies have also shown that toxic dinoflagellates are poor competitors compared to Prymnesiophyceae (Riegman et al. 1996) and even compared to non-toxic dinoflagellates (Cannon 1996). As in mixed cultures without 
copepods where the growth rate of Prorocentrum micans was higher than Alexandrium minutum, it might be interpreted as a lower nutrient uptake affinity of toxic dinoflagellates than non-toxic dinoflagellates. However, to prove this hypothesis it would be necessary to generate normalised growth rate curves versus nutrient concentrations for both algal species.

All the studies mentioned above clearly showed that dinoflagellates are poor competitors under nutrient limitation. However, blooms of toxic dinoflagellate species are frequent in nutrient-depleted waters. Smayda (1997) suggested that toxin production could be an adaptation evolved to offset the ecological disadvantages of dinoflagellates with low nutrient affinity. The enhanced toxin production observed in Alexandrium minutum, and in other toxic marine phytoplankton species as nutrient concentration diminished, seems to corroborate his hypothesis. Since PSP toxins are nitrogenous compounds, in PSP producing dinoflagellates, a reduced amount of toxin per cell is observed under $\mathrm{N}$ limitation (Boyer et al. 1987, Anderson et al. 1990), but toxin production is higher under $\mathrm{P}$ limitation (Boyer et al. 1987, Anderson et al. 1990, also this study). Moreover, it is important to point out that, in agreement with our results, Anderson et al. (1990) showed that this enhanced toxin production in Alexandrium spp. under P limitation was not an indirect consequence of nutrient influence on growth rate. This lack of relationship between specific growth rate and toxin production rate could be due to toxins being synthesized from low molecular weight metabolites, while cell growth is a much more complex process. Our experimental design has the problem that algae were grown at high $\mathrm{NO}_{3}^{-}$concentrations (Table 1) as compared to the field nutrient concentrations. John \& Flynn (2000) mentioned that in high-N systems factors causing a cell-density-dependent cessation of growth may adversely affect cell physiology and hence, they suggested that experiments using more than $100 \mu \mathrm{M}$ of $\mathrm{N}$ may give rise to unrepresentative physiological responses. However, Anderson et al. (1990) observed in batch-culture experiments similar toxin content per cell in Alexandrium spp. cultured with $\mathrm{NO}_{3}^{-}$initial concentrations of 880 and $20 \mu \mathrm{M}$. As the lowest $\mathrm{NO}_{3}^{-}$concentration used by Anderson et al. (1990) is closer to field concentrations, high toxin production in PSP producing dinoflagellates could also be observed with the nutrient concentrations found in the field. In those marine toxic phytoplankton species which produce toxins with a low elemental $\mathrm{N}$ and $\mathrm{P}$ composition, cellular toxicity increases both under $\mathrm{N}$ and $\mathrm{P}$ limitation (Johansson et al. 1996, Granéli et al. 1998, Johansson \& Granéli 1999a,b). This link between toxin production and nutrient availability could explain why cultured Alexandrium cells are typically less toxic than those col- lected from natural populations in the same region (Cembella 1998). When the strain of Alexandrium minutum used in this study was isolated from the field, toxin content per cell was $\sim 18 \mathrm{fmol}$ (Franco et al. 1994). However, as the algae have been cultured for a long time under optimal conditions, toxin content per cell of this long-established population is now only about $1.1 \mathrm{fmol}$.

If the ecological significance of toxin production was only to deter grazers, toxin content per cell would be high under any nutrient concentration. The linkage between toxin production and nutrient concentration indicates that toxin production is also related to interspecific competition. Although some toxin-producing algal species excrete their toxins into the surrounding water (see Johansson \& Granéli 1999a), gonyautoxins are intracellular compounds (Anderson \& Cheng 1988, Doucette \& Anderson 1993) and hence, toxins produced by Alexandrium minutum could not inhibit the growth of potential competitors by the excretion of toxins into the water. Therefore, we concluded that in addition to feeding avoidance, another ecological advantage of toxin production by Alexandrium minutum under P limitation is to offset interspecific competition by redirecting grazing pressure onto non-toxic phytoplankton species that are potential competitors.

Acknowledgements. We thank Andrew G. Bauder and José Franco for useful comments on the manuscript. This research was supported by Project MAR96-1822, a grant from the Chilean Government to M.F., an FPU grant to I.M., a grant from FUNDACIÓN PROVIGO to I.R. and a grant from AECI to A.R.V. We thank Charo Carballo for useful help with nutrient analyses. Nutrient concentrations were kindly provided by Centro de Control do Medio Mariño (Xunta de Galicia).

\section{LITERATURE CITED}

Anderson DM, Cheng PTO (1988) Intracellular localization of saxitoxins in the dinoflagellate Gonyaulax tamarensis. J Phycol 24:17-22

Anderson DM, Kullis DM, Sullivan JJ, Hall S, Lee C (1990) Dynamics and physiology of saxitoxin production by the dinoflagellates Alexandrium spp. Mar Biol 104:511-524

Béchemin C, Grzebyk D, Hachame F, Hummert C, Maestrini SY (1999) Effect of different nitrogen/phosphorus nutrient ratios on the toxin content in Alexandrium minutum. Aquat Microb Ecol 20:157-165

Boyer GL, Sullivan JJ, Andersen RJ, Harrison PJ, Taylor FJR (1987) Effects of nutrient limitation on toxic production and composition in the marine dinoflagellate Protogonyaulax tamarensis. Mar Biol 96:123-128

Cannon JA (1996) Competition between the dinoflagellates Alexandrium minutum and Prorocentrum micans in the Port River, South Australia. In: Yasumoto T, Oshima Y, Fukuyo Y (eds) Harmful and toxic algal blooms. Proc 7th Int Conf Toxic Phytoplankton. Intergov Oceanogr Comm, UNESCO, Paris, p 381-384

Carlsson, P, Granéli E, Finenko G, Maestrini SY (1995) Cope- 
pod grazing on a phytoplankton community containing the toxic dinoflagellate Dinophysis acuminata. J Plankton Res 17:1925-1938

Cembella AD (1998) Ecophysiology and metabolism of paralytic shellfish toxins in marine microalgae. In: Anderson DM, Cembella AD, Hallegraeff GM (eds) Physiological ecology of harmful algal blooms. NATO ASI Series, Vol G 41. Springer-Verlag, Berlin, p 381-403

Donaghay PL, Small LF (1979) Food selection capabilities of the estuarine copepod Acartia clausi. Mar Biol 52:137-146

Doucette GJ, Anderson DM (1993) Intracellular distribution of saxitoxin in Alexandrium fundyense. In: Smayda TJ, Shimizu Y (eds) Toxic phytoplankton blooms in the sea. Elsevier, p 863-868

Dutz J (1998) Repression of fecundity in the neritic copepod Acartia clausi exposed to the toxic dinoflagellate Alexandrium lusitanicum: relationship between feeding and egg production. Mar Ecol Prog Ser 175:97-107

Flynn KJ, Franco JM, Fernández P, Reguera B, Zapata M, Wood G, Flynn KJ (1994) Changes in toxic content, biomass and pigments of the dinoflagellate Alexandrium minutum during nitrogen refeeding and growth into nitrogen or phosphorus stress. Mar Ecol Prog Ser 111:99-109

Franco JM, Fernández P (1993) Separation of PSP toxins by reversed phase high performance liquid chromatography, with postcolumn reaction and fluorimetric detection. Chromatographia 35:613-620

Franco JM, Fernández P, Reguera B (1994) Toxin profiles of natural populations and cultures of Alexandrium minutum Halim from Galician (Spain) coastal waters. J Appl Phycol 6:275-279

Frangópulos M, Guisande C, Maneiro I, Riveiro I, Franco JM (2000) Short-term and long-term effects of the toxic dinoflagellate Alexandrium minutum on the copepod Acartia clausi. Mar Ecol Prog Ser 203:161-169

Granéli E, Johansson N, Panosso R (1998) Cellular toxin contents in relation to nutrient conditions for different groups of phycotoxins. In: Reguera B, Blanco J, Fernández ML, Wyatt T (eds) Harmful algae. Proc 8th Int Conf on Harmful Algae. Intergov Oceanogr Comm, UNESCO, Paris, p 321-324

Huntley M, Sykes P, Rohan S, Marin V (1986) Chemicallymediated rejection of dinoflagellate prey by the copepods Calanus pacificus and Paracalanus parvus: mechanism, occurrence and significance. Mar Ecol Prog Ser 28:105-120

Ives JD (1987) Possible mechanism underlying copepod grazing responses to levels of toxicity in red tide dinoflagellates. J Exp Mar Biol Ecol 112:131-145

Johansson N, Granéli E (1999a) The influence of different N:P supply ratios on cell density, chemical composition and toxicity of Prymnesium parvum (Haptophyta) in semicontinuous cultures. J Exp Mar Biol Ecol 139:243-258

Johansson N, Granéli E (1999b) Cell density, chemical composition and toxicity of Chrysochromulina polylepis (Haptophyta) in relation to different N:P supply ratios. Mar Biol 135:209-217

Johansson N, Granéli E, Yasumoto T, Carlsson P, Legrand C (1996) Toxin production by Dinophysis acuminata and $D$. acuta cell grown under nutrient sufficient and deficient conditions. In: Yasumoto T, Oshima Y, Fukuyo Y (eds) Harmful and toxic algal blooms. Intergov Oceanogr Comm, UNESCO, Paris, p 277-280

John EH, Flynn KJ (2000) Growth dynamics and toxicity of Alexandrium fundyense (Dinophyceae): the effect of

Editorial responsibility: Otto Kinne (Editor),

Oldendorf/Luhe, Germany changing N:P supply ratios on the internal toxin nutrient levels. Eur J Phycol 35:11-23

Maneiro I, Frangópulos M, Guisande C, Fernández M, Reguera B, Riveiro I (2000). Zooplankton as a potential vector of diarrethic shellfish poisoning toxins through the food webs. Mar Ecol Prog Ser 201:155-163

Ogata T, Ishimaru T, Kodama M (1987) Effect of water temperature and light on growth rate and toxicity change in Protogonyaulax tamarensis. Mar Biol 95:217-220

Oshima Y (1995) Post-column derivatization HPLC methods for paralytic shellfish poisons. In: Hallegraeff GM, Anderson DM, Cembella AD (eds) Manual on harmful marine microalgae. IOC (Intergovnt Oceanogr Comm) Manuals and Guides No 33, UNESCO, Rome, p 81-94

Oshima Y, Sugino K, Yasumoto T (1989) Latest advances in HPLC analysis of paralytic shellfish toxins. In: Natori S, Hashimoto K, Ueno Y (eds) Mycotoxins and phycotoxins. Elsevier, p 319-326

Parkhill JP, Cembella AD (1999) Effects of salinity, light and inorganic nitrogen on growth and toxigenicity of the marine dinoflagellate Alexandrium tamarense from northeastern Canada. J Plankton Res 21:939-955

Plumley FG (1997) Marine algal toxins. Biochemistry, genetics, and molecular biology. Limnol Oceanogr 42:1252-1264

Riegman R, De Boer M, De Senerpont Domis L (1996) Growth of harmful marine algae in multispecies cultures. J Plankton Res 18:1851-1866

Shaw BA, Andersen RJ, Harrison PJ (1997) Feeding deterrent and toxicity effects of apo-fucoxanthinoids and phycotoxins on a marine copepod (Tigriopus californicus). Mar Biol 128:273-280

Smayda TJ (1997) Harmful algal blooms: Their ecophysiology and general relevance to phytoplankton blooms in the sea. Limnol Oceanogr 42:1137-1153

Teegarden GJ (1999) Copepod grazing selection and particle discrimination on the basis of PSP toxic content. Mar Ecol Prog Ser 181:163-176

Teegarden GJ, Cembella AD (1996) Grazing of toxic dinoflagellates, Alexandrium spp., by adult copepods of coastal Maine: Implications for the fate of paralytic shellfish toxins in marine food webs. J Exp Mar Biol Ecol 196:145-176

Turner JT, Tester PA (1997) Toxic marine phytoplankton, zooplankton grazers, and pelagic food webs. Limnol Oceanogr 42:1203-1214

Turner JT, Tester PA, Hansen PJ (1998) Interactions between toxic marine phytoplankton and metazoan and protistan grazers. In: Anderson DM, Cembella AD, Hallegraeff GM (eds) Physiological ecology of harmful algal blooms NATO ASI Series, Vol G 41. Springer-Verlag, Berlin, p 453-474

Turriff N, Runge JA, Cembella AD (1995) Toxic accumulation and feeding behavior of the planktonic copepod Calanus firmanchicus exposed to the red-tide dinoflagellate Alexandrium excavatum. Mar Biol 123:55-64

Uye S, Takamatsu K (1990) Feeding interactions between planktonic copepods and red-tide flagellates from Japanese coastal waters. Mar Ecol Prog Ser 59:97-107

Wyatt T, Jenkinson I (1997) Notes on Alexandrium population dynamics. J Plankton Res 19:551-575

Yamamoto T, Tarutani K (1996) Growth and phosphate uptake kinetics of Alexanrium tamarense from Mikawa Bay, Japan. In: Yasumoto T, Oshima Y, Fukuyo Y (eds) Harmful and toxic algal blooms. Proc 7 th Int Conf Toxic Phytoplankton. Intergov Oceanogr Comm, UNESCO, Paris, p 293-296

Submitted: November 6, 2000; Accepted: April 24, 2001

Proofs received from author(s): December 13, 2001 